\title{
台風進行速度が台風下の有義波・最大波に及ぼす影響
}

\section{Significant and Maximum Waves under Typhoons with Different Traveling Speed}

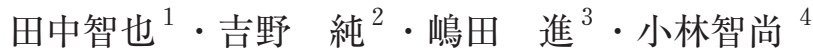 \\ Tomoya TANAKA, Jun YOSHINO, Susumu SHIMADA and Tomonao KOBAYASHI
}

\begin{abstract}
Characteristics of significant and maximum waves under strong wind of typhoons are analyzed numerically by applying the wave model SWAN and the maximum-wave estimation proposed by Mori et al. The traveling speed of typhoons is changed in the numerical simulations and its influence to the significant and the maximum waves is investigated. The largest wave height occurs when the typhoon's traveling speed is a little smaller than the group velocity of the corresponding significant waves. The directional and frequency concentrations in the wave spectrum are also inclease with the speed, and it causes of the largest maximum-waves.
\end{abstract}

\section{1. はじめに}

台風下の風域は強風で方向が特定されている。このた め, この強風下の波浪は分散性が低いまま急激に発達し, 特殊な波浪場になっていると想像される.

台風に伴う波浪場の解析は従来より行われているが, それらは比較的広い領域での特性解析であり, 台風内で の波浪場の解析はあまり行われていない。台風内では特 に局所的かつ短時間で波浪が高波へと発達し，災害の要 因になりうる。しかし台風内の波浪の発達が局所的・短 時間であるため, これまでその把握が困難であり, 台風 下で急激に発達する波浪の特殊性についてはほとんど行 われていない.

そこで本研究では波浪推算を用いて, 台風内での有義 波および最大波の特徴について, 特に台風の進行速度が 波浪場に及ぼす影響について検討した。

\section{2. 波浪場の再現方法}

\section{(1) 数値計算モデル}

本研究では, 台風下の波浪場を数值モデルで再現する と共に，発生する最大波の推定も行った.

台風下での波浪場を波浪推算モデル SWAN（Booijら， 1999）を用いて再現した．SWANはすでに多くの場で実 績があり（例えば，川崎ら，2010）, 本研究でも有用と 判断した.

最大波の推定には森ら（2008）の異常波浪出現に関す る推定式を用いた。彼らは波浪スペクトルの周波数分散 および方向分散の影響を評価し，これらの分散性が小さ

\begin{tabular}{|c|c|c|}
\hline 1 & 修 (工) & $\begin{array}{l}\text { 名古屋大学大学院 工学研究科 社会基盤 } \\
\text { 工学攻 }\end{array}$ \\
\hline 2 正会員 & 博 (理) & $\begin{array}{l}\text { 岐阜大学准教授工学研究科環境エネルギー } \\
\text { システム尃攻 }\end{array}$ \\
\hline 3 & 博 (工) & (独法) 産業技術総合研究所 \\
\hline 4 正会員 & 博 (工) & $\begin{array}{l}\text { 岐阜大学教授 工学研究科環境エネルギー } \\
\text { システム専攻 }\end{array}$ \\
\hline
\end{tabular}

いほど異常波の発生頻度が上昇するとしている．本研究 ではこの推定式を元に，300波での最大波を本論文内で の最大波とした。この 300 波は約 1 時間に相当する.

\section{（2）再現対象の台風}

対象とする台風は1216（2012年台風16号）とした。

この台風の進路を図-1に示す．図のとおりこの台風は ほぼ直線的に北上しており，図中青印のとおり9月16日 に九州南西海上で中心気圧 $935 \mathrm{hPa}$ の極大に達している. 図中の赤実線は中心気圧 $945 \mathrm{hPa}$ 以下であった最盛期の 経路区間である。

\section{（3）波浪再現条件}

波浪推算モデル SWANおよび森ら（2008）の最大波推 定式による波浪場の再現条件を表-1に示す。

波浪推算モデル SWANによる再現性の検証として， 表-1の条件で得られた，名瀬での推算結果を国土交通省 全国港湾海洋波浪情報網（NOWPHAS）速報值と比較・ 検証した。その際には地形の影響を考慮するため，表-1

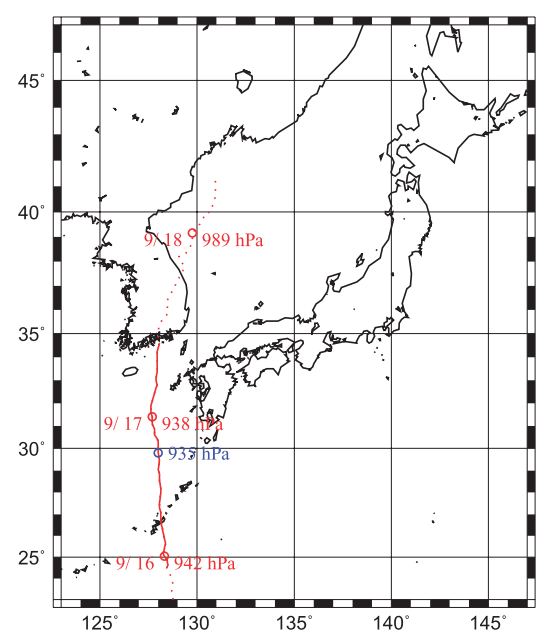

図-1 対象の台風1216の経路（青印は極大時，赤実線は中心 気圧 $945 \mathrm{hPa}$ 以下の経路区間を示す) 
表-1 波浪場再現計算の計算条件

\begin{tabular}{|c|c|}
\hline \multicolumn{2}{|l|}{ 数值モデル } \\
\hline 波浪推算モデル & SWAN \\
\hline 最大波推定法 & $\begin{array}{l}\text { 森ら(2008) } \\
300 \text { 波（約1時間相当）最大波 }\end{array}$ \\
\hline \multicolumn{2}{|l|}{ 計算領域·期間 } \\
\hline 計算領域 & $\begin{array}{l}\text { 東経 } 120.0^{\circ} \sim 150.0^{\circ} \\
\text { 北緯 } 22.4^{\circ} \sim 47.6^{\circ}\end{array}$ \\
\hline 格子間隔 & $\begin{array}{l}5 \mathrm{~km} \\
\left(\text { 経度方向 } 0.0625^{\circ}, \text { 緯度方向 } 0.05^{\circ}\right)\end{array}$ \\
\hline 期間 & $\begin{array}{l}\text { 2012年9月 10日9時〜9月 20日8時 } \\
\text { (入力海上風の実期間) }\end{array}$ \\
\hline 境界条件 & 開境界条件（ネスティングなし） \\
\hline \multicolumn{2}{|l|}{ 入力データ } \\
\hline 海上風 & $\begin{array}{l}\text { 気象庁メソ数值予報モデル GPV } \\
(5 \mathrm{~km} \text { 格子, 1時間間隔 })\end{array}$ \\
\hline 海底地形 & 全域深海を仮定 \\
\hline
\end{tabular}

の記述とは異なり, 海底地形には実地形データを用いた. この検証結果を図-2に示す。図のように，高波浪時を除 く期間では有義波高 $H_{\mathrm{s}}$, 最大波高 $H_{\max }$ とも波浪推算モデ ルの再現性は良好であるが，9月16日，17日の高波浪時 にはモデルは波高を過大評価する傾向が見られる．この 点については, 調査・改善の必要があると認識している.

本研究の数值計算ではこの様な傾向が見られるが，こ こでの議論は波高の相対的関係を議論するので，特に修 正等は行わず，議論を進める.

表-1の通り海上風には気象庁のメソ数值予報モデル GPVの 1 時間間隔データを用いた. そして本研究では台 風の進行速度を変化させるために，この海上風デー夕の 時間間隔を変化させた。この方法では台風本体の回転風 速場と進行速度との合成風速場を正確には再現できない が，台風進行速度にかかわらず風速場の強度を同一にで きる.この事から波浪場の比較解析に適しているとして, ここで採用している.このように海上風データの時間間 隔を変化させているために，それに対応して波浪推算モ デル上の計算期間も変化している.

また図-1に示す対象領域には陸域や浅海域が含まれて いる.しかしここでは台風による影響のみを検討するた め, 領域内全域で深海と仮定して条件を与えた。ただし 本研究では実台風を対象としており，陸域などの影響は

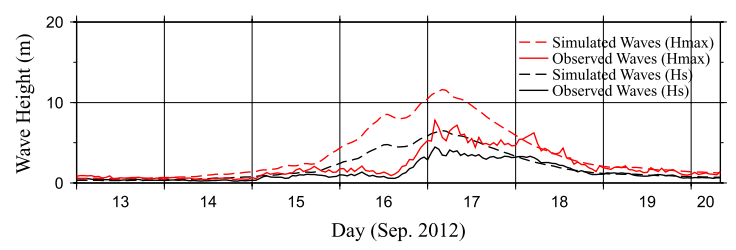

図-2 有義波高 $H_{\mathrm{s}}$, 最大波高 $H_{\max }$ の数值計算結果と観測值と の比較（2012年 9 月, 名瀬)
台風の風域場にも影響しているために, 解析結果では陸 域などの影響を完全には除去できていない.

\section{3. 台風下での波浪の再現}

\section{（1）波浪場の再現}

図-3に2012年9月16日18時における, 海上風, 有義波 高 $H_{\mathrm{s}}$, および最大波高 $H_{\max }$ と有義波高 $H_{\mathrm{s}}$ との比 $H_{\operatorname{maxx}} / H_{\mathrm{s}}$ の分布を示す。また図-4には台風の発達に伴う中心気圧 の時間変化の他, 有義波高 $H_{\mathrm{s}}$, 最大波高 $H_{\max }$, 波高比 $H_{\text {max }} / H_{\mathrm{s}}$ の空間ピーク值の時系列を示す.

図-3 (a) の風速分布と図-3 (b) の有義波高 $H_{\mathrm{s}}$ 分布との 比較より, 従来からの指摘の通り, 危険半円である台風 の中心から進行方向右側 (東側) の領域で有義波高 $H_{\mathrm{s}}$ の ピークや波高の大きい領域が存在している.

図-3 (c) に示される波高比 $H_{\max } / H_{\mathrm{s}}$ では, 東日本周辺な ど台風から遠方の領域で見られる通り, 通常では 1.7 程 度の值となるが, 台風中心近傍では 2.0 近くの值を示し ていることがわかる。,一方図-4では, 台風が発達し中心 気圧が低下するに従い, 有義波高 $\mathrm{H}_{\mathrm{s}}$, 最大波高 $H_{\max }$ とが 増加すると共に, 波高比 $H_{\max } / H_{\mathrm{s}}$ も増加していることがわ かる.これら図-3 (c), 図-4より, 台風内の強風により波 は急激に発達するため, この波浪の周波数集中度および 方向集中度が高くなり, それに従って波高比 $H_{\max } / H_{\mathrm{s}}$ も大 きい值を示していると考えられる，ただし図-4に示すよ うに, 台風中心気圧が最低となる9月16日の同時刻に有 義波高 $H_{\mathrm{s}}$ も極大となるが, 波高比 $H_{\max } / H_{\mathrm{s}}$ や最大波高 $H_{\max }$ は, 同日深夜から翌 17 日早朝に掛けて, やや遅れて 極大に至っている.

\section{（2）台風進行速度と波高ピーク発生位置との関係}

次に台風中心を基準とした波高ピーク発生の相対位置 と, 台風進行速度がそのピーク発生位置に及ぼす影響を 議論する。ここでは任意の時刻における空間で, 最大の 波高を示す位置を波高ピーク発生位置と呼ぶこととする.

図-5に, 台風 1216 の台風最盛期（中心気圧 $960 \mathrm{hPa}$ 以 下）における有義波高ピーク発生相対位置を示す. 四の (a), (b), (c) では台風の進行速度が異なり, 実進行速 度での結果である図(b) に対して, 図(a) は台風進行速 度を半減, 図 (c) は逆に速度を 1.5 倍とした場合の解析 結果である. 図中, 台風中心を座標軸原点とし, 縦軸正 方向を台風進行方向としている.したがって図の第 1,4 象限は台風の危険半円側となる. 図-5 (b) に示すとおり, 台風最盛期に有義波高のピークは台風進行方向右側約 40 $\mathrm{km}\left(\right.$ 約 $\left.0.5^{\circ}\right)$ からやや前方の離れた地点に位置している. この結果は図-3 (a), (b) の結果とも対応している.こ れに対して, 台風進行速度半減の図-5 (a) では, 図 (b) に比べて有義波高のピーク発生位置は台風進行方向のよ り前方に位置している. 逆に台風進行速度を 1.5 倍とし 


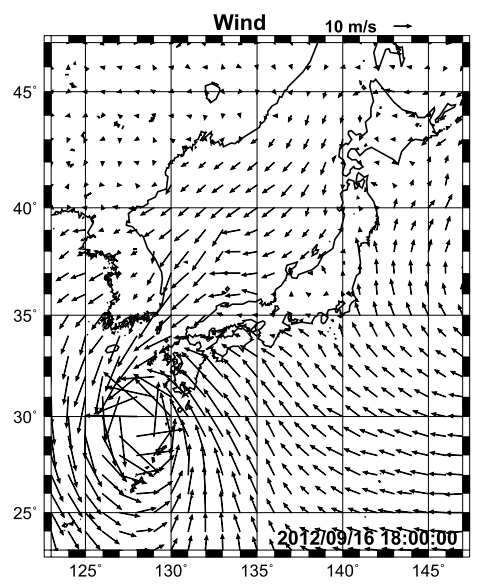

(a) 海上風向風速

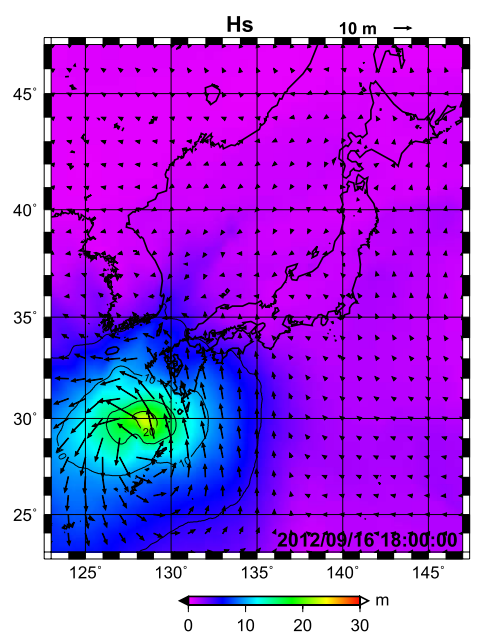

(b) 有義波高・波向

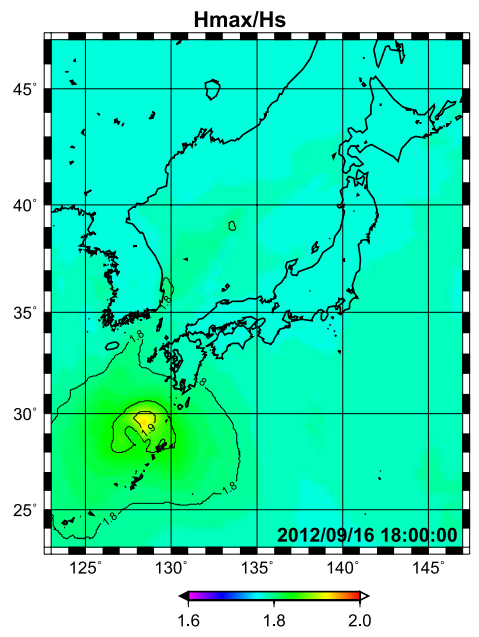

(c) 最大波有義波波高比

図-3 台風1216来襲時の海象状況（2012年9月16日 18 時, 領域全域深海条件
た図 (c) では，台風進行方向後方に後退している。これ は台風進行速度を半減した場合，波高のピークを示す有 義波の波速や群速度が台風の進行速度より大きく, 台風 を追い越して前方に移動するためである。逆に台風進行 速度が大きいときには波高のピークを示す有義波が台風 に追従できず後退している，また台風進行速度が小さい 図-5 (a) は, より速度の大きいケース, 図 (b), (c) に比 ベてピーク地点の変動が少ない。これは台風の進行速度 が小さいために，海上風から有義波への運動量輸送が安 定していると共に, 波浪場も発達状態から定常状態に近 づいているためである.

最大波高ピーク発生位置についても台風中心を基準と した場合，図-5に示す有義波のケースと同様の傾向が見 られた。

有義波高ピーク発生位置と最大波高有義波高比のピー ク発生位置ついても検討する。図-6に有義波高ピーク発 生位置を基準とした最大波高有義波高比 $H_{\max } / H_{\mathrm{s}}$ ピーク発 生位置を示す。前図と同様に，図の（a)，（b），(c）の進 行速度は順に，半減，実進行速度，1.5 倍，である。最大 波高ピークの相対的発生位置は大きく変動している。ま た台風進行速度半減時には, 最大波高有義波高比のピー ク発生位置は有義波高ピーク発生位置とほぼ同位置であ るが, 台風進行速度が増加すると共にその位置は台風進 行方向に対して後退している。これは台風の進行速度が 大きい場合には波高のピークを示す有義波が台風の進行 速度に追従できず，十分には発達できていないためと考 えられる。

\section{（3）台風の進行速度が波浪場に及ぼす影響}

最後に台風進行速度が波浪発達へ及ぼす影響について 議論する．台風進行速度に対する，有義波高 $H_{\mathrm{s}}$ や最大波 高 $H_{\max }$ ，最大波高有義波高比 $H_{\max } / H_{\mathrm{s}}$ のピーク值を図-7に 示す。これらの図では台風進行速度を波高がピークとな る有義波の波速や群速度で無次元化している。図中には 台風進行速度を実測值の他，1/2 から4倍まで変化させ， 台風 1216 の最盛期（中心気圧 $940 \mathrm{hPa}$ 以下）の結果をプ ロットしている。

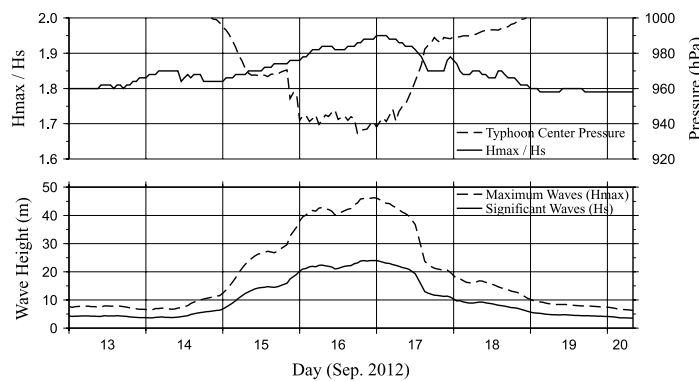

図-4 台風中心気圧と, 有義波高 $H_{s}$, 最大波高 $H_{\max }$, 最大波 有義波波高比 $H_{\max } / H_{\mathrm{s}}$ の空間ピーク值との時系列 
有義波高 $H_{\mathrm{s}}$ および最大波高 $H_{\max }$ のピーク值に関する 図-7 (a)，（b）から台風下において最も波浪が発達する のは，有義波高が最大值を示す波浪の群速度より，台風 の進行速度がやや小さい場合であることがわかる．台風 下で波浪が効率的に発達するためには，その波浪が台風 下の強風から継続して運動量を供給される様に，台風の 進行速度が有義波の群速度と同程度となっていることを

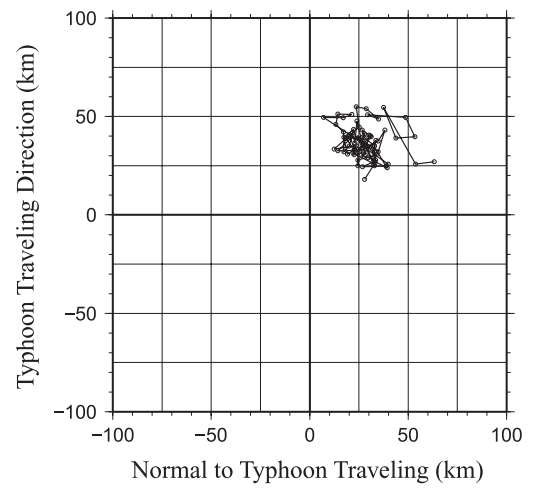

(a) 台風進行速度半減時

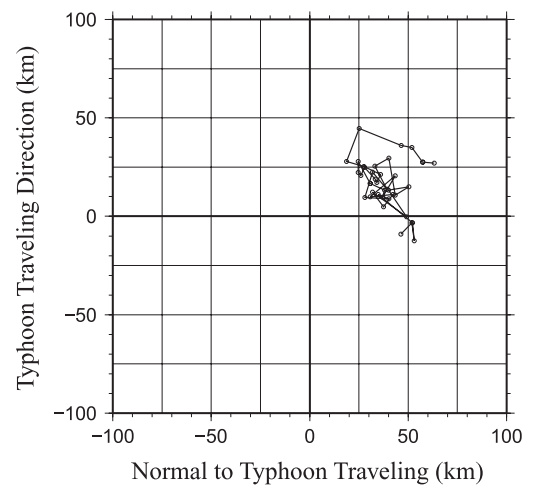

(b) 実台風進行速度時

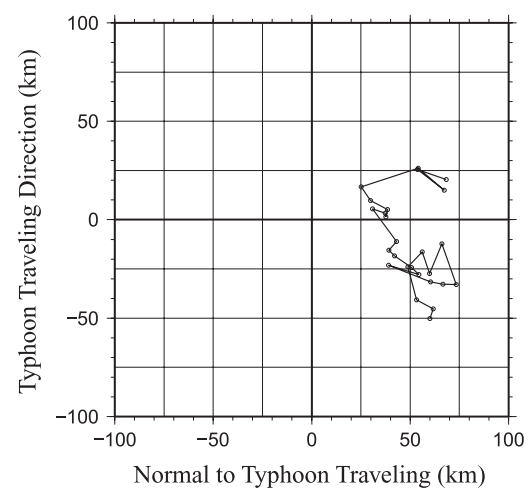

(c) 台風進行速度 1.5 倍時

図-5 台風中心に対する, 有義波高のピーク発生相対位置 （台風中心気圧 $960 \mathrm{hPa}$ 以下）
示している，ただし本解析で台風進行速度がこの群速度 より小さい值で有義波高が最大となっているのは, 対象 波浪自体が時間的に発達しており，定常的な解析ができ ないためであると考えられる。

同様に最大波高有義波高比 $H_{\max } / H_{\mathrm{s}}$ のピーク值に関する 図-7 (c) からも, 波高比 $H_{\max } / H_{\mathrm{s}}$ のピーク值が最大となる のは, 有義波高がピークの波浪の群速度より台風の進行

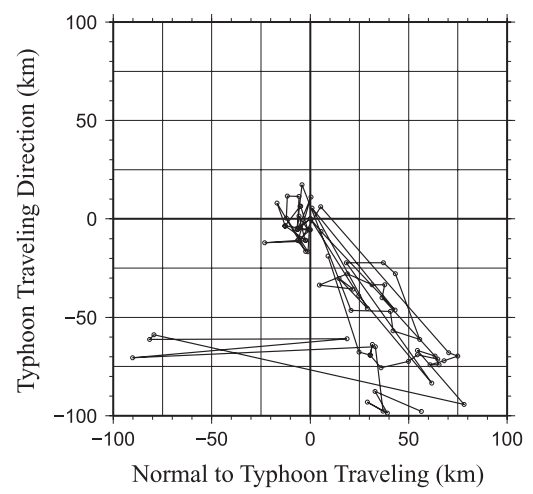

(a) 台風進行速度半減時

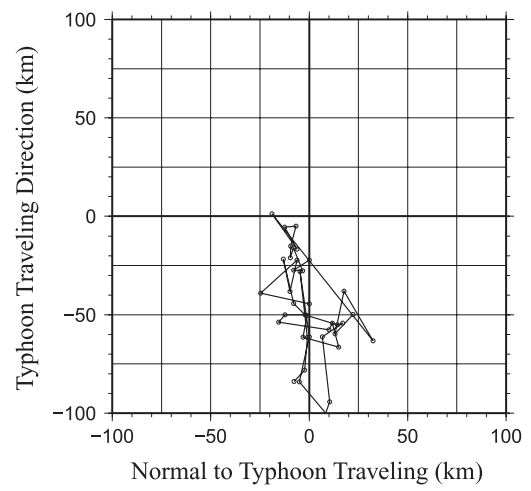

(b) 実台風進行速度時

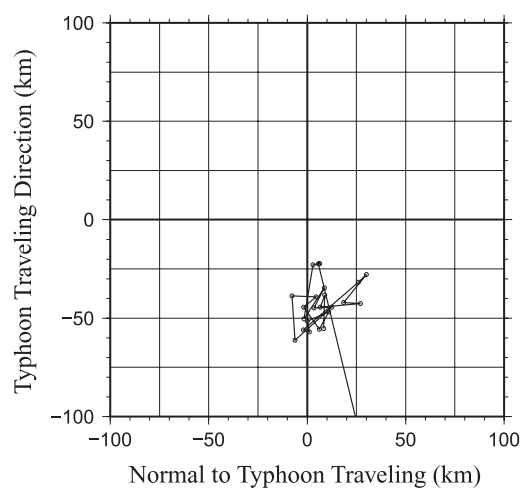

(c) 台風進行速度 1.5 倍時

図-6 有義波高ピーク発生位置に対する，最大波高有義波 高比ピーク発生相対位置（台風中心気圧 $960 \mathrm{hPa}$ 以下） 
速度がやや小さく，有義波高に関する図-7 (a) の結果と 同様あることがわかる．有義波高のピーク值が最大にな る台風進行速度の条件下では，波浪が効率的に発達する ため，この波浪の周波数及び方向の分散性が小さく，結 果として最大波高有義波高比 $H_{\max } / H_{\mathrm{s}}$ が大きくなったと考 えられる.

以上のことから，台風下において有義波高のピーク值 が最大を示す台風進行速度はその波浪の群速度よりやや

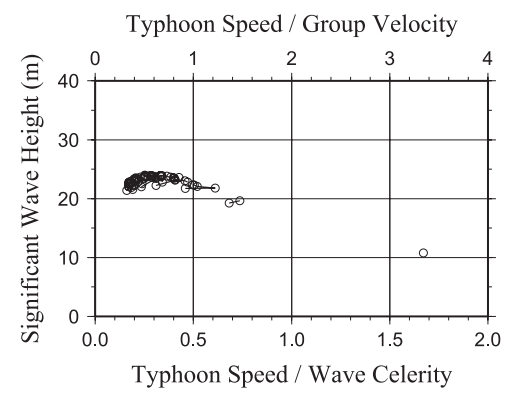

(a) 有義波高 $H_{\mathrm{S}}$

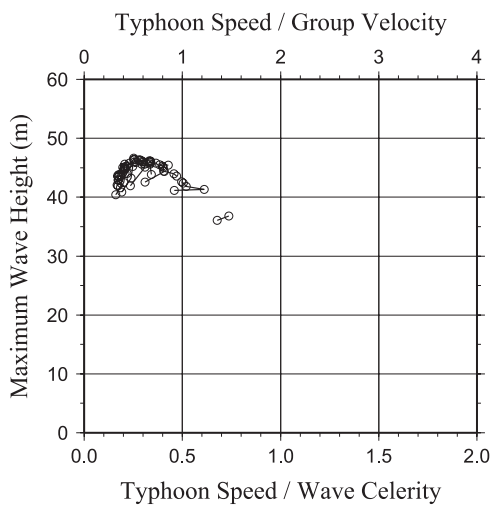

(b) 最大波高 $H_{\max }$

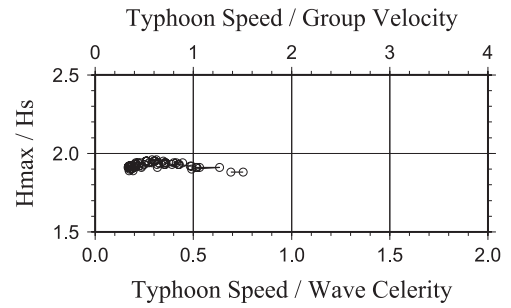

(c) 最大波高有義波高比 $H_{\max } / H_{\mathrm{S}}$

図-7 異なる台風進行速度を対象とした，台風速度に対する 波高および波高比のピーク值（中心気圧940 hPa 以下， 台風進行速度は対応する有義波の波速・群速度で無次 元化)
小さい場合であり，またその際には最大波高有義波高比 $H_{\max } / H_{\mathrm{s}}$ も大きな值となることが示された.

\section{4. おわりに}

本研究では台風下での波浪場やその発達特性につい て，特に台風進行速度が波浪場に及ぼす特性について検 討した。ここでは台風1216を対象に波浪推算モデルを用 いて，異なる台風進行速度の海上風場で複数の波浪場を 再現した。そして特に台風下での有義波高や最大波高の ピーク值やその発生位置, 最大波高有義波高比 $H_{\max } / H_{\mathrm{s}}$ の ピーク值やその発生位置について解析を行った.

その結果，台風下での有義波高や最大波高のピークは 台風進行方向右側の危険半円内で生じていたが，台風の 進行速度が大きい場合には波浪が追従できず，そのピー ク位置は台風中心より後方に後退していた，逆に台風進 行速度が小さい場合にはそのピーク位置は台風中心より 前方に移動していた，有義波高ピーク位置に対する，最 大波高有義波高比 $H_{\max } / H_{\mathrm{s}}$ のピーク発生位置についても同 様の傾向が見られた。

また台風下の波浪が発達し，有義波高や最大波高のピ ーク值が最大となる台風進行速度は，有義波高がピーク となる波浪の群速度よりやや小さいことが示された。こ の台風進行速度では波浪が台風下の強風から継続して運 動量供給されるために，その波浪が効率的に発達するた めであった. また，最大波高有義波高比 $H_{\max } / H_{\mathrm{s}}$ のピーク 值も群速度よりやや小さい值で最も大きくなった.

本研究により, 台風下で発達する波浪の特徵, 特に台 風進行速度に対する特徴が明らかとなった。

謝辞：本研究では，国土交通省全国港湾海洋波浪情報網 （NOWPHAS）のデータを活用しました。ここに謝辞を 表します.

\section{参 考 文 献}

川崎浩司・丹羽竜也・水谷法美（2010）：高波の影響を考慮し た高潮・高波汇濫モデルの構築とその精度検証, 土木学 会論文集B2（海岸工学），第66巻，pp.196-200.

（独法）港湾空港技術研究所：全国港湾海洋波浪情報網（ナウ ファス), http://www.pari.go.jp/unit/kaisy/nowphas/, 参照 2013-05-18

森 信人・Peter A.E.M Janssen ・ 川口浩二（2008）：多方向性 を考慮した異常波浪予測モデルの提案とその検証，海岸 工学論文集, 第 55 巻, pp.111-115.

Booij, N.R., R.C.Ris and L.H.Holthuijsen (1999) : A thirdgeneration wave model for coastal regions, Part I, Model description and validation, Journal of Geophisical Research, Vol. 104, No.C4, pp.7649-7666. 